\title{
ALASTAIR MCAULEY
}

\section{The Woman Question in the USSR}

WOMEN IN RUSSIA. Edited by Dorothy Atkinson, Alexander Dallin, and Gail Warshofsky Lapidus. Stanford: Stanford University Press, 1977. xiv, 410 pp. $\$ 18.75$.

With a pardonable degree of oversimplification, the Marxist analysis of the "woman question" can be paraphrased as follows: Women's inferior status under capitalism is a consequence of their dependence upon men within the context of the bourgeois family. This in turn derives its raison d'être from the existence of private property. The implication is thus clear: the abolition of private property will lead to farreaching changes in the nature of the family; it will lead to the emergence of women from the confines of the domestic hearth, to their assumption of the full range of political, economic, and social roles. The socialist revolution, then, will result in the eradication of sexual inequality and of exploitation of women by men, just as it will result in the elimination of class inequality and the exploitation of workers by the owners of property.

The essays in the volume under review (a selection of papers given at a conference on the status of women in Russia held at Stanford University in the summer of 1975 ) allow one to assess the validity of this analysis. They provide a valuable addition to our knowledge of the political, social, and economic position of women in the Soviet Union today. They also offer some fascinating insights into the course of female emancipation in the USSR over the past fifty or sixty years. The Stanford conference was an ambitious attempt to bring together American scholars working on the topic in a variety of disciplines, and the papers in the volume reflect this eclecticism. The resulting publication is not without its faults, but it should constitute essential reading for students of Soviet social history, sociology, politics, and economics for years to come. It can also be read with profit by those with an interest in the wider field of women's studies.

What, then, is the status of women in the USSR today? How successful have Soviet authorities been in achieving sexual equality? How valid is the Marxist analysis of the sources of female subordination? As several papers document, women now play an extensive role in the Soviet economy. Rates of female labor force participation in the USSR are probably the highest in the world, and women make up approximately half of the gainfully occupied population. Moreover, women are found in substantial numbers in a range of professional and semiprofessional occupations (for example, as physicians, pharmacists, and even engineers) that are usually male preserves in most Western countries. Second, substantial numbers of women can be found in positions of political responsibility-particularly in the state (Soviet) hierarchy and in the judiciary. Finally, despite problems in the area of illegitimacy and paternity and a certain amount of sex-specific legislation in the field of employment, for the most part, neither the legal system nor standard administrative procedures make distinctions on the basis of sex. 
Noteworthy as these achievements are, however, they do not imply that sexual equality has been attained in the USSR. First, as the papers by Sacks, Dodge, and Ethel Dunn demonstrate, women are still basically confined to subordinate executive positions. Even in sectors in which women make up a majority of the work force, the bulk of managerial and administrative positions are held by men. This pattern is repeated in the political sphere: almost all the higher party posts (from the obkom upward) are still occupied by men, as they always have been. As a result, the earnings of women are, on the average, less than those of men. (There appear to be two factors at work here: first, within any enterprise or occupation more men than women are found in managerial positions or skilled grades; second, the occupations and sectors in which women predominate tend to have lower rates of pay than those in which men form the bulk of the labor force.) Also, although the details are too complicated to be developed in an essay of this length, the papers by Juviler and Madison suggest that the practical application of the law and the character and provisions of specific social services result in a disadvantageous treatment of women, particularly those with children.

Women in Russia goes beyond mere documentation of sexual inequality in the USSR; a number of authors attempt to explore the factors responsible for the continuing inferior status of females and to ascertain how far they are the consequences of deliberate policy rather than unintended side effects. For example, in a first-rate paper, Dobson examines the education of women and suggests that the educational system acts to transmit inequality rather than to generate it. That is, the interaction of manpower planning and the differing career preferences of boys and girls make it somewhat more difficult for girls to obtain places at vuzy, in spite of their numerical superiority in the upper classes of the secondary schools. Thus Dobson identifies the socialization process as a key factor which determines the aspirations of Soviet women. This is examined in more detail by Schwartz Rosehan, whose paper is suggestive but far from complete, because her conclusions appear to go beyond the evidence she adduces. On the basis of content analysis of a limited number of primarygrade readers, she demonstrates the existence of sex-role typing and the tendency to associate more desirable character traits with males. I demur, however, from the proposition, stated on page 301 , that

women are mothers first and "something else" second. Very little richness of description or detail is assigned to women's jobs, whereas their mothering roles are elaborated. The lesson is possibly not lost on young Soviet readers: women have jobs, men have careers.

Before such a conclusion can be established, surely one should examine the material to which older children are exposed. Also, before drawing inferences about the impact of such material, the author should have analyzed recent evidence about the vocational aspirations of girls in the upper grades of secondary schools (discussed by Dobson on pp. 277-82).

The second factor-adduced by a number of authors-which accounts for the relatively low level of achievement by women in the Soviet economy and polity is the so-called double burden borne by a majority of Russian women. As a large number of Soviet studies have shown, primary responsibility for running the home and caring for children falls upon the woman. As a result, particularly after marriage and the birth of their first child, women have far less time and energy to devote to further education, to the acquisition of additional skills, or to the pursuit of voluntary political or social activity. The burden of housework falling upon women is aggravated by the primitive nature of the services sector in the USSR and also by the perpetuation of attitudes among men that regard most domestic activities as "women's work." 
The interaction of attitudes and aspirations on the one hand and of educational opportunities and domestic responsibilities on the other forms the core of an explanation of the continued inferiority of women in the USSR. The Soviet experience thus casts doubt upon the adequacy of the traditional Marxist solution to the "woman question." There are two aspects to this failure. First, as Alfred Meyer argues in a very perceptive paper, neither Marx nor Engels devoted a great deal of thought to the problems faced by women under capitalism or to the way that they would be resolved under socialism; as a result, their analysis remained abstract and largely unrelated to any program of action. Further, the early socialists who did try to develop a more relevant analysis (like Bebel or Lily Braun) encountered indifference or outright hostility. Neither the German nor the Russian parties were prepared to accept the emphasis which Braun in particular placed upon the changes in consciousnessamong males as well as females-that would have to occur before the position of women could be decisively improved. Nor did they find the stress that these authors laid upon happiness and personal fulfillment congenial. Rather, the analysis put forward by Klara Zetkin came to be accepted as Marxist orthodoxy, and it clearly subordinated the problem of women to the class struggle. It was also more mechanistic and "materialist." Thus, even before the atrophy of creative political thought in Russia in the 1930s, the dominant perception of the "woman problem" was formal and inadequate. And there has been little attempt since the "thaw" to reexamine any of these questions on a theoretical level. This suggests that what we see as continuing problems may not be perceived as such in the USSR, and that the Soviet concept of a solution to the "woman problem" and, indeed, of equality between the sexes may differ fundamentally from our own. Unfortunately, this theme is not pursued in Women in Russia, although a number of authors touch upon it.

Second, as Gail Lapidus argues cogently, it would be wrong to believe that finding a solution to the "woman problem" has occupied a central position in Soviet priorities. Rather, the changes that have occurred in the status of women in the USSR since the Revolution have, more often than not, resulted from the pursuit of other goals. Lapidus suggests that political and legal enfranchisement in the 1920s was, in large part, a result of the regime's attempts to create a new political community, to undermine preexisting loyalties and commitments, and to acquire a degree of legitimacy. Similarly, economic enfranchisement (mobilization) was the outcome of the ambitious industrialization drive of the 1930 s and, more recently, of the impact of political-military upheavals upon the availability of male labor. Finally, both the extent of the double burden and recent tentative steps to alleviate it through reform of social services and extensions to the services sector are at least as much the result of concern about future labor supply as they are of concern for the quality of life enjoyed by Soviet women.

The analysis offered in Women in Russia, insofar as one can ascribe a common viewpoint to its authors, suggests that the persistence of sexual inequality in the USSR can be ascribed to inadequacies in the formulation and implementation of official policy. In part, this is attributable to limitations in Soviet conceptions of the problem, and in part, to authorities' failure to pursue the goal of Marxist equality single-mindedly. The papers included in this volume raise wider issues, however, and prompt a number of reflections. In a paper on the debates surrounding the introduction of the 1926 marriage law. Beatrice Brodsky. Farnsworth describes a proposal (by Alexandra Kollontai) to introduce a system of social insurance against desertion (of wives by their husbands). This raises the general issue of the nature of the family and the scope of social policy: In what sense is desertion similar to unemployment or ill health, and what would be the consequences of social (or even private) insurance against such a risk? More generally, how far should individual women (and men) be expected to assume responsibility for the upbringing of their own children? Indeed, can such personal obligations be reconciled with Kollontai's conception of the sexually free, 
radical new woman? I suspect not. These issues are not pursued by Beatrice Farnsworth, and there is no reason why they should be. But one would have liked to see somewhere in the volume an examination of changing Soviet conceptions of the family in a unified form (rather than as a subsidiary theme in a variety of papers).

The changes in the status of women that have occurred in the USSR have presumably had an impact upon Soviet men, upon their perceptions of themselves and of the nature and extent of their obligations. These have also been affected by recent demographic history (the existence of a substantial surplus of women of marriageable age for much of the Soviet period). It is to be expected that these changing attitudes have affected the course of female emancipation. Yet, too often, the contributors to this volume write as though male attitudes have remained frozen in some archetypal patriarchal mold.

Finally, there is the issue of pronatalism. Declining birth rates in the postwar period have resulted in an incipient (and potentially serious) shortage of labor. This has prompted a far-reaching reexamination of the desirability of alternative demographic policies. It has also resulted in extensive academic discussions of possible modifications of existing social welfare programs. Both of these elements have implications for the future status of women in Russia (some of which are ably explored in Gail Lapidus's paper). But it also raises the broader question of reconciling the biological function of maternity with women's other aspirations and of the extent to which alternative social objectives may be legitimately pursued by a government committed to sexual equality. These issues scarcely emerge in this volume, and the inadequacies of the conceptual framework within which Soviet policy is discussed make the analysis of the question less than convincing. 